\title{
中国庭園の墻と門空の特色
}

\section{Feature of the Garden Wall and Gate $\cdot$ Window in China}

\author{
河原 武敏 \\ Taketoshi Kawahara
}

\begin{abstract}
Key Words：1.特色 2. 墙・門空 3 . 中国庭園
\end{abstract}
\section{Feathre 2. Garden Wall and Gaite -Window 3. Cina}

はじめに

本文が対象とする「墻」は、庭園に関係す る建物壁面または景区を分割する墻を意味 し、「阴空」とは、墙の開口部である門洞と 漏空・空空をいう。日本にこうした墙はあ まり見受けられないが、中国庭園にとって は独特の庭園構成に必要な施設であり、ま たそれが作る框景は注目に值する。本文は その基本として応用される計成の《園治》 を主として、その特色を明らかにしたい。

\section{1. 墻と門空の意義}

\section{(1)景の造成}

園墻に直接門空を設置する理由に框景の 効用がある。これは墻の内部を絵の様に見 せながら、来園者を或る境地に誘うことは 独特の景観手法としてよく知られている。

この一幅の框景を作るため、明末清初の 著名な造園家計成の《園治》には、「門空の 框の中は磚を磨いて作り、その様式は当時 の流行にしたがって造る心゙きである。これ によって建物が新しく変るばかりか、庭園 も更に雅趣を増す」とあり、墻に設けられ た門答の存在効果を重視している。そして 技術者の腕の見せ所であるとし「工事精緻
さは、主として瓦職人によるものであるが、 その計画は人を得て始めて出来るのであ る」とあり、それを計画段取りする設計者 の存在を重視している。更にその装飾につ いて「洞門に彫刻は嫌われるが、空は細か く工夫して作るべきである」としている。

このように墙に門空を取り付ける理由は、 単に人の出入りや通風採光ではなく、外景 を生きた画面のように額縁の中、即ち框景 へ納める効果を期待寸ることにある。その ため単調な墻面に生動ある趣を作るよう、 通路に門洞、格子のある漏空、格子のない 空空〔洞空〕を設け。景の造成に寄与して いる。

廊沿いに門洞、漏空、空空を設け、庭景 を見え隠れさせる例に蘇州の留園がある。 延長 700 余mの廊下に見せる 30 余の異な るこれら開口部は、各々鑑賞の重要な見ど ころとして注目されている。

\section{(2)審美的価值}

（i 隔景作用： 大規模な庭園では「園中の 園」を設ける場合が多い。一般に「子園」 と称され、それを仕切る園墻は洞門, 漏空, 空慜とともに周囲の景色と虚実対比の作用 を作る。ここでいう虚実とは「虚の中に寒 
がある 実の中に虚がある」といら意味で、 この種の空間効果は多重景観を構成し「有 界非界」「小中見大」「变化無究」の効果を 作り出している。

（ii）借景作用：墻面に取り付けられた開 口部背後に景石や竹木を配置し，密から恰 も画のような框景学作り出す。これを「景 中有景 画中有景 是画是景」と称し、そ の作用と工法に付いて《園治》には「門空 の框内傅を磨いて作る。人が園内の景致 に遇うと奇想が湧き、心の中に情を秘めた 風致が加わる。例えば軽い紗を張った空の 外に碧玉の緑がめぐり、柳の若葉も哯いて いる。目前の大きな石が人を迎え、あたか も別天地を作る。風で竹影が摇れ、笙の音 が聞こえてくるようだ。一空前の所及に 空き地を置き景物を近くに配置するとよ いとある。これらは明末清初の頃から江 南の庭園で大きく発達し、中国庭園の優れ た技法の一つとして今に伝えられている。

\section{2. 園墙について}

\section{(1)目的}

「園墙」は磚、石、版築等を積んで園内 を仕切る壁体をいう。これは単なる隔壁で はなく、独特の景観を作ることもできる。 これに就いて《園冶》巻 6 墻垣の項には「従 来の墻垣はすべて工匠まかせであり、精巧 な花鳥, 神仙、怪獣などを彫刻している。 このようなものは庭園でも堂前でもよいと はいえないと過度な装飾に注意している。

園墙設置の目的は一般に建物や景物が高 密度に分布しているため、変化に富んだ園 景を作るには、園墙で幾つかの景区に区分 し、景物の多重変化を少しでも増や扵必要 があり、「園中有園 景中有景」を作る重要
な役割を果たしている。

\section{(2)造形の工夫}

墻は単調で重苦しいので次のように造形 上の工夫がなされている。

(i 形態の変化 : 地勢に合わ世、平坦地 には「平墙」、斜面には「階段墙」[梯級墙〕。 必要に応じて「高墙」「低墻」を高低結合し、 或は墙の威圧感を避けるため上部に生動起 伏寸る波形状の「雲埭」「龍墙」を設ける場 合もある。

その有名な例に上海の豫園の「龍墙」が あり、狭い園内に「小中見大」の効果を与 えている。墙上に 4 種類の龍が墻の上部に 設けられ、その1は点春堂と万花楼の間で、 龍頭の下に彩雲が天空に跳衫上がる「穿雲 龍」そその 2 は大仮山背後の墙上に潜み、機 会あれば起き上がろうという「卧龍」そその 3 は和煦堂の西側にある民族色豊かな珠を 持つ 2 匹の「双龍双珠」その 4 は内園に女 り青瓦の藍天に白雲のような「白龍」であ る。

（ii)淡雅な色彩:景物を引き立たせるた めに墻面を清楚な白色とし、その上に黒色 の屋根瓦を蒀いて色彩を淡く目立たぬよう 配慮される。特に白墻の墻面は画紙に見立 てられ、墙前に置かれた山石や花木を絵の ように輪郭を際立をせ、更に壁面一映る影 の変化に趣を感しとっている。これを「粉 墙為紙 以石為絵」という。

（iii）墻面に門空 : 墙面には框景を造る 洞門・漏空・空空を取り付け、さらに付近 に山石花木を脇添えして、単調な墙に変化 を与えている。

\section{（3）構造と工法}

墙の構造には様々ある。南方の庭園では 高温多湿に適した薄壁の中空墙が多い。皇 
家庭園の紅色や勅願寺の黄色など華美な色 彩に対し、私家庭園は白色の墙、灰色の棟 瓦、褐色の門空が組み合わされて地味なが ら落ち着きのある色彩が用いられる。昔か ら伝わる工法を《園冶》では次のように述 ベている。

（i ）白粉墙：「表面に紙の繊維と石灰を 混ぜて塗布した墙である。時には光沢を取 り去り、白蝉を塗り、面を平らに磨きあげ る。よく用いられるのは、江湖の黄砂を下 地に石灰を少しばかり塗り、更に薄く石灰 を前面に叙布して、麻篣木で軽く擦ると自 然に光沢が出て鏡のようになる。もし污れ たなら洗い去ればよい。かくて鏡面墻とい う。」とある。ここでいら「江湖」とは長江 と洞庭湖のことである。

（ii）磨磚墙：「正門内を隠す照墻や庁堂 前の墙面に用いられ、水磨磚や四角の磚を 斜めに貼り付ける。或は方磚を八角に切っ て隙間に小方磚を嵌り、或は小䂪の中 に半分の方磚を挟んだり、または花形に筑 いて錦のような紋様にする。墙頂には水磨 きの軒用方磚を幾層にも積み重㸚る。墙に 花鳥、神仙、怪獣だどの夙刻は用いない。 画意が少ないからである。」

（iii）漏磚墻：「凡そ眺望のよい所にこの 墻を設ける。これは内景を檃して外から見 えないようにするため、昔は切断した瓦で 連銭、畳錠、魚鱗などの模様を作ったが今 は一般に行われていない」「連銭」は2つ 以上の円を連結した模様。「畳錠」は元代の 銀貨幣である銀錠の模様をいう。

（iv）乱石墙：にこの墻は乱石を積み重祆て 造る。乱石には黄石が最も適し、大小の石 は互いに間隔をあける。この墙は仮山の間 に交えて造るのがよい。青石で乱石墙を造
るには、油灰で接着させ、この種のものを 水裂墻という。」ここでいう「油灰」とは石 灰に桐油を混ぜた接着剤のことである。

（v）漏明墙：「こ机には凡气 16 式ある。 思うにその中から堅固なものを採用すれば よい。欄干式の中から造るものもあるが、 この中から採用するわけではない。それは 様式が重なる恐れがあるからで、この種の 墻には磨磚造りが最適である。とあり 26 種が図示されている。この墙は北方で「花 磚墻」「透空墙」、南方の蘇州から上海一帯 では「花墙洞」「透空磚墙」ともいわれてい る。

これら種類のうち「漏磚墙」と「漏明墙」 について、陳植と張家騜はこの 2 種類は同 じ墙として解説している。

\section{3、洞門について}

\section{(1)目的}

「洞」の意味は、洞窟のほかに貫通した 穴から見通すという意味がある。したがっ て「洞門」とは、墙に開けられた出入り口 から内部が見通せる門をいう。「洞空」も同 様の意味をもつ。これらは来園者の進路誘 導を果をすと同時に、門内の景物を見通し て美しい框景を作り出すことができ、日照 の変化によって多彩な影が墙に映る。この ように墙を庭園空間に挿入すると、多重の 奥行きを作る効果が生じる。

\section{(2) 形状と種類}

来園者の出入りする所なので、その高さ 々幅に注意する必要がある。洞門下部は地 面に接し、人の幅よりやや大きめに作る。 その形状は一般に縦向きで閏扉は付けない。 とくに主要景区を構成する洞門には、簡潔 で直径の大きな円洞門と八角洞門がよく用 
いられ、歩廊や小規模の中庭では軽妙な縦 長形、圭形、長八角形が多く、隅飾りにも 変化を付ける

種類には直線型、曲線型、混合型がある。 多くは通行しやすい左右対称形で、庭園の 意境に合わせ様々工夫されている。《園冶》 では洞門の形式について「予がこれを伝へ ないと、忘れ去られる心配がるので、次の 図に示しておく」と記しているが、その心 配は杞憂に過ぎず、今なお多くの形式が工 夫されている。つぎに《園冶》で紹介する 洞門形式を【図 1】に示す。

（i）方門合角式：「昔は磨磚を用いた矩 形門はアーチ作りの工匠に任せて作った。 それには碍の上に石を横架させた過門石、 または角材を架した過門枋を置いたもので あった。現在の矩形門は、木釷を用いてつ なぎ、過木枋の上で磚とホゾを合わせる。 そう寸れば見る心゙き雅致が得られる。とあ り、横架材を架設にも使用したらしい。

(ii)圈門〔券門・アーチ門〕式:「凡そ磨 磚の門空は必ず墙の厚薄を計り、磚の大小 を考える。アーチ内の磚面は露出している ので、すべて研ぎ出した磚を用い、縁辺は 一寸ほど厚くする。」磚の外縁以外怯石灰を 塗るか、或はすべて研ぎ出しにする。《園冶》 の指図には「縁辺は一寸ばかりにし、内側 はすべて研ぎ出し仕上げにする」と記して いる。

（iii）上下圈式: 《園治》に:示された図に よると、「すべて門空の縁には筋目を付け る」とある。

（iv）その他：《園冶》で図示された諸形 式には、入角式、長八方式、執圭式 葫芦 式 蓮弁式 如意式 貝葉式 剣環式 漢 瓶式 4 種 花㑡式 耆草式 月空式 片月
式 八方式 六方式 菱花式 如意式 梅 花式 葵花式 海棠式 鶴子式、貝葉式 六方嵌柧子式 栀子花式 罐式がある。こ のほかにも、長六角式 定勝式 桃式 漂 篎式 [葫芦式] 秋葉式などがあり、また長 方式上縁の中央が突起し、或は $3 . \cdot 5$ 本の 弓形を呈しているものや隅飾りを設けるも のもある。中でも人の通行しやすい形式は 円洞門(月洞門)と八角洞門で、来園者の多い 所では楕円月門や横向洞門もよく採用され ている。走廊や小院では直長, 圭角、長八 角など軽妙なものが多い。

\section{（4）磚框の工法}

開口部の磚框には灰青色の方磚が嵌めら れ、その上に「線脚」を付ける。これには 縮渋線、木角線、亜面、渾面、文武面など の形式があり、また方門合角式洞門の上部 隅を飾るものに門景もある。

縁框の工法は、まず方碍の背面に蟻継の 溝を掘り、板に柄を作って溝にはめて重量 を受け、板尻はそのまま墙の本体に組み入 れる。縁框の面取りは、磚用の鋸や鉋で円 面を作り、細目の砥石で滑らかに磨きあげ る。取り付け後はパテで目地を詰め、更に 豚血を混ぜた磚屑を磚の表面と面取りの隙 間に詰め、最後に乾燥し細目の砥石で再び 滑らかに磨き仕上げる。

\section{4. 漏空と空公について}

\section{(1)定義}

「漏空」は「花空」とも称される。これ は空に取り付けられた格子紋様から外光が 漏れ、変化に富んだ陰影が生じて趣深い。 格子のない言を「空空」または「洞空」「月 洞」とも云われ、空の目的である通風採光 以外に、生き生きした美しい外景を額縁で 
切り取った絵のように見せる。そのため小 規模の中庭では悹の背後に小空閒を設け、 石峰、芭蕉、竹、花木などを配置し、空か ら見て一幅の絵画のように作ることが多い。 これには屝は取り付けない。

\section{(2)効用}

空の高さは一般に $1,5 \mathrm{~m}$ 内外、下框までは 床面から $1,3 \mathrm{~m}$ 程度のものが多い。この高さ は空を通じて外の景物を眺めるのに適して いる。通風採光専用の空はかなり高い。墙 で隠された美しい景の一部を空から採りい れ、身近に自然空間を感じさせる。

\section{(3)形状}

空の外形は環境に応じて横向き、縦向 き、正方形など様々な形状がある。幾何学 図形には直線、孤線、円形、六角形、八角 形、扇形があり、その中の直線は万字、定 勝、六角景、菱花、書状、緤環、橄欖、氷 裂紋など。孤線は魚鱗、銭紋、球紋、秋葉、 海棠、葵花、如意、波紋などがあり、これ らの混合には效紋、万字海棠、六角穿梅花、 灯景などや特殊なものに琴、基、書画など を幾何学図形で囲んだものもある。また自 然図形には花卉類の題材が多く、松、柏、 梅、竹、蘭、菊、牡丹、芭蕉、蓮、仏手柑、 石榴など。鳥獣の題材には獅子、虎、雲龍、 蝙蝠、鳳凰など、人物故事の題材には小説 伝奇・仏教故事・歴史伝説、劇中の一場面 などがある。複合図形には、六角と穿花、 松と鶴、柏と鹿なども目にし、これら紋様 数は蘇州だけで数百種は下らないといわれ ている。その代表的な例を庭園別に紹介す ると、【図2】のようである。

その他、特殊なものに「什錦空」がある。 これは庭園内外に框景を作り、墙に取り付 けた空の内外にガラスをはめ、それに絵を
画き、中に灯具を置いて明かり空としたも のである。これは北方の四合院に多く、江 南でも見受けられる。

建築に多い「空空」には簡潔素朴な横長、 縦長、方形のものが多い。また連続して歩 廊に取り付ける空笞は、あまり大きくなく、 形式は様々で配列も踈密取り混ぜて単調さ を避けている。

\section{(4)工法}

幾何学図形の紋様空は瓦片、薄磚、木材など で作る。その短直線には化粧軒下地磚を使 い、長さの不足や複雑な什錦紋には木片や 孤線など種々な瓦を用いる。また複雑な自 然図形には、木片や竹筋、後に鉄筋、鉄棒、 鉄板が用いられ、細部の仕上げには、骨組 み上にモルタルや麻系等を何層にも巻き付 けて塗りこめ、セメントペーストやモルタ ルを重祇て形を整える。

ほかにガラスを嵌めた既製空もあるが、 これらは幾何学模様で耐久性はあるが単調 なので使用例は少ない。

\section{(4)李漁の框景空}

明末清初の計成 (1582〜) は「借景」を 更に発展させ、墙に美しい外景を風雅な空 枠内に採り入れた風雅な空を《園治》に紹 介し、庭園景観の進歩に大きな足跡を残し た。これを更に普及させたのは李漁（1611 〜1680）である。彼の著《閑情偶寄》には、 「景を取るということは、それを借りるこ とにある〔取景在借〕と称し、「湖舫式」

「尺幅空図式」「梅空」の 3 種類を提案し、 その経緯を記して大いに世間の注目を浴び た。

(i )湖舫式扇形公: 彼が杭州西湖の傍らに 住んだをき、自分の遊覧船に扇形空を両脇 に取り付け、「湖舫式」と命名し「船の左右 
に扇面突のほか開口部はなく、船に座って さえいれば、両岸の景色が扇に画いた“天 然の画”のように見える。というのがそれ である。【図 3 】

（ii）尺幅空図式：また彼は庁堂内に新し く自然を入れる方法として「無心画」「尺幅 空」といら框空を作って人々を驚かせてい る。【図 4】即ち「遂に侍童に命じて画紙を 幾つも切裂き、空枠のように上下左右に貼 ってみた。これはあたかも一幅の画のよう だが、それは虚であって実ではない。建物 の背後のある山を画に代えたものである。 座してこれを見ると密ではなく画である。 つまりその山は建物背後の山ではなく、画 面上の山である。妻子達が集まって思わず 狂ったような笑声があがった。私もまた大 笑いした」と言うのがそれである。ここで 云う“無心”とは「框ありて心なし」。“尺 幅”とは「尺幅千里」の意味がある。

（iii）梅空：更に彼は枯れた枝に紙の梅花 を貼り付计を漏寒を作った【図 $5 】$ 「「私は 試外に枯れ枝を数本採って、天然の空を作
り “梅空”とした。一出来上がった後 で、人工の花を剪って紅梅と緑募の $2 つ に$ 分け、粗い枝と細い茥に取り付けたところ、 あた加生きた梅の花のようになった」と ある。

\section{結び}

小規模の庭園ほど景区の変換点は工夫が 必要である。本文では、中国庭園の墙とそ の門空に見出し、その框景を含む効果と技 法を考察した。この手法は明末清初の計成 の《園冶》によって詳しく紹介されたもの いで、今なお゙様々な形態が工夫され、利用 されている。

わが国でも古来、框景の技法は存在する ものの、園の界墻に用いた例はあまり見当 たらない。本文の考察はわが国の新たな施 設計画の参孝に供することが出来るものと 考光る。以上

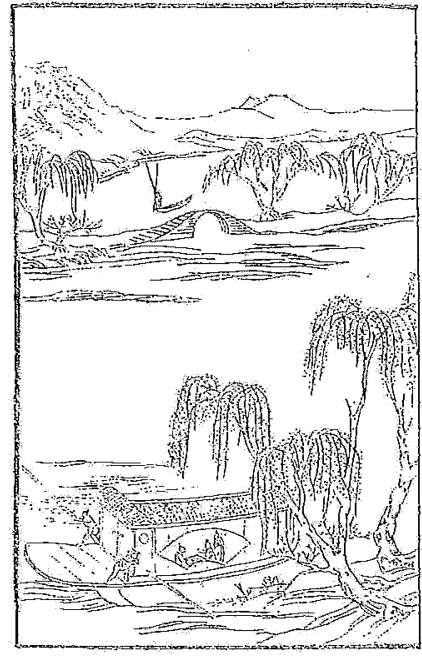

【図 3】湖舫式

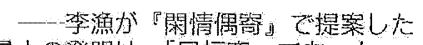
最大の登明は, 「民幅䓌」であった。 空陁学 $2<\emptyset$,

外側の景色存市たかも 山水画のことく，

室内人之移入さ西。

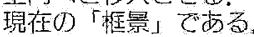
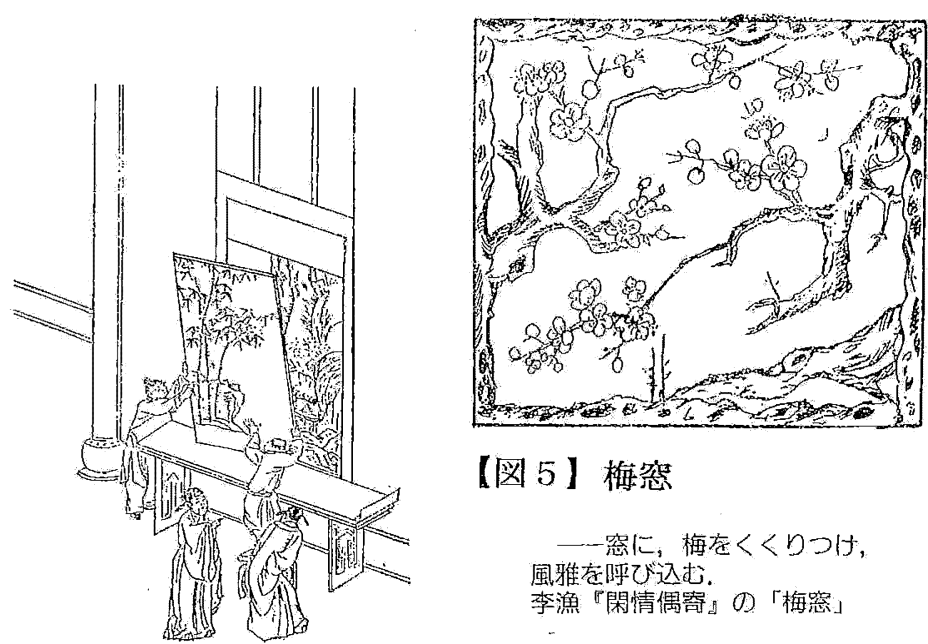

【図 5】梅空

一一空に，梅症くくりつけ， 阅雅定呼び込む。 李漁『閑情偶寄。 D「梅管」

\section{【図 4】尺幅空図式}

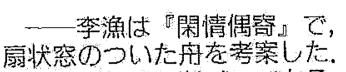

かれの言う「湖舫式」である。 


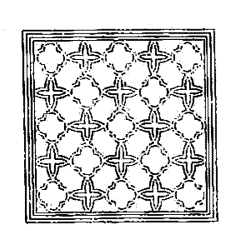

古木交柯

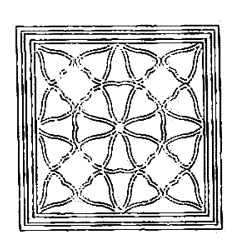

古木交柯

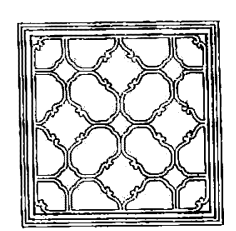

古木交柯

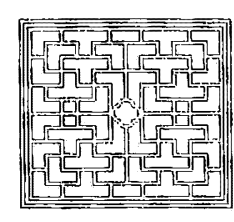

古木交柯

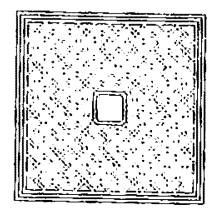

古木交柯

留園。

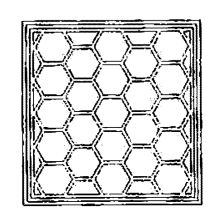

古木交柯

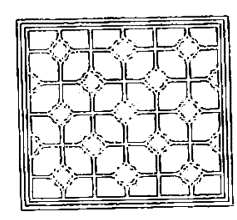

古木交柯

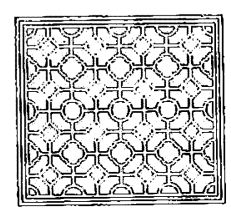

古木交柯

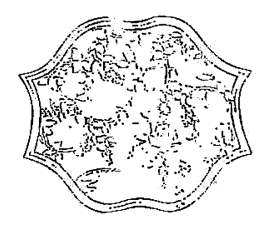

指柏軒

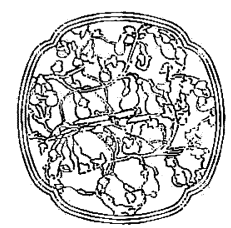

指柏軒

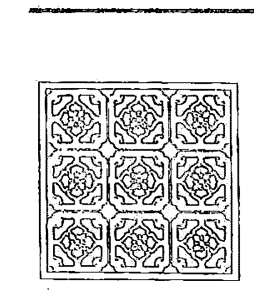

問梅閵

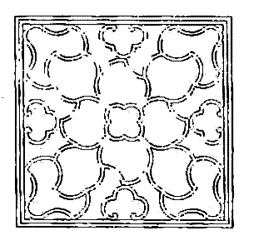

䜩誉堂

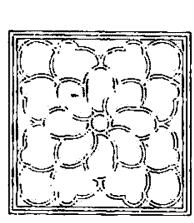

燕举堂

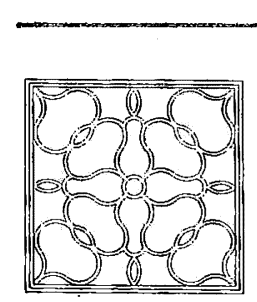

小方庁

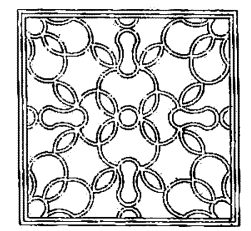

燕誉堂

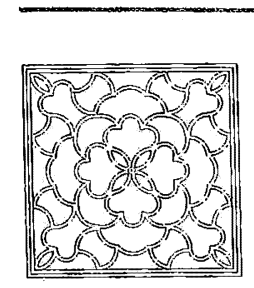

燕誉堂

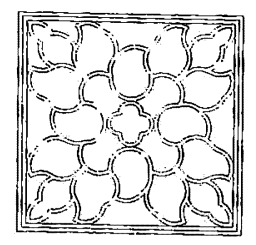

燕誉堂

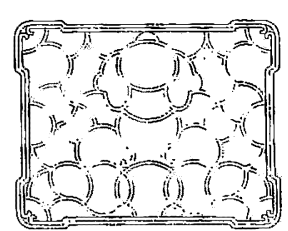

築山遊歩廊

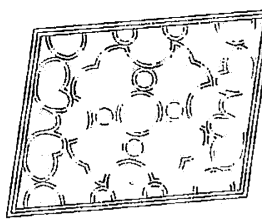

築山遊歩瑯

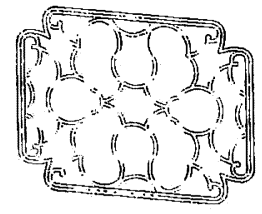

築山遊歩瑯

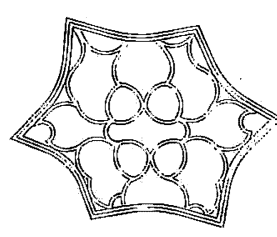

筑山遊歩廊

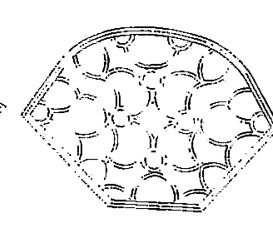

築山遊歩廊

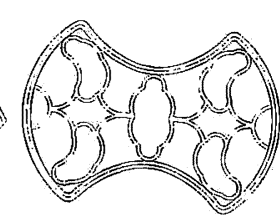

筑山遊歩廊

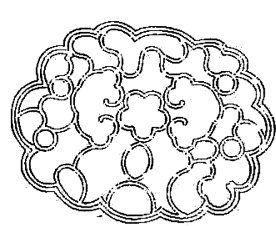

築山遊歩廊

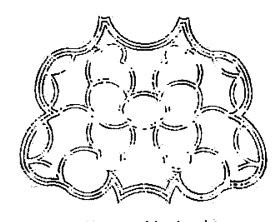

築山遊步廊

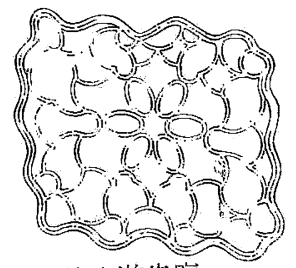

築山遊歩廊
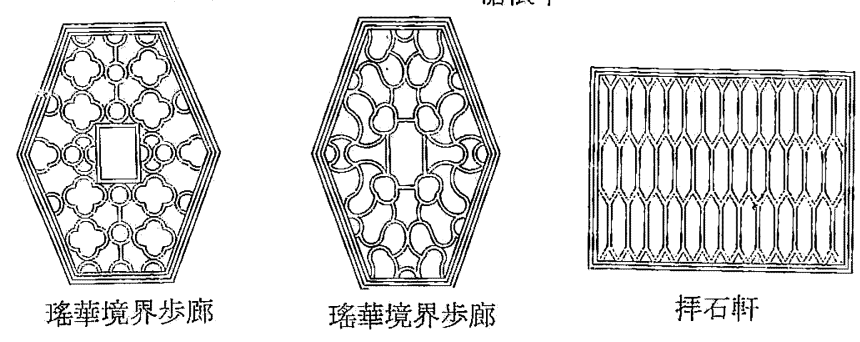

拝石䀒

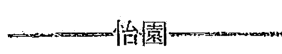

【図 1 蘇州に見る漏空の例〔〔劉敦楨《蘇州古典園林》から再編〕 


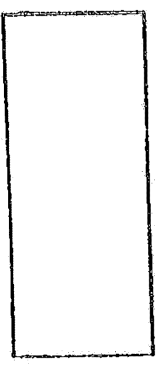

方門合角式

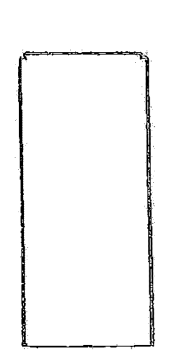

入角式

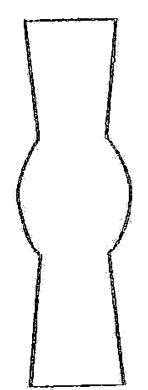

花触式

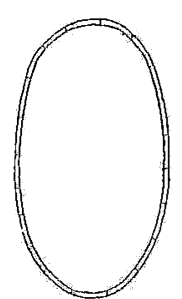

鶴子式

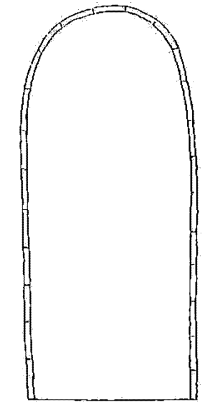

圈門式

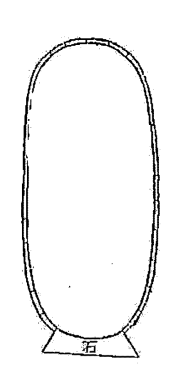

上下圏式

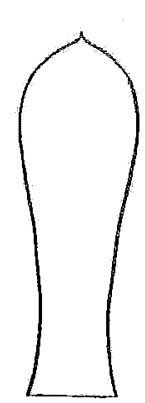

蓮弁式

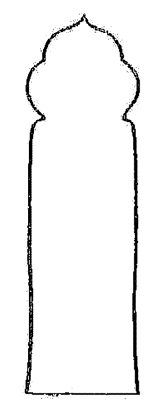

如意式

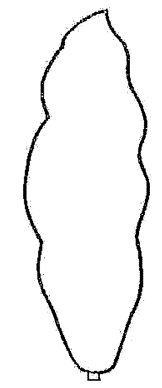

具葉式

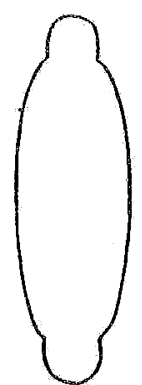

剣環式
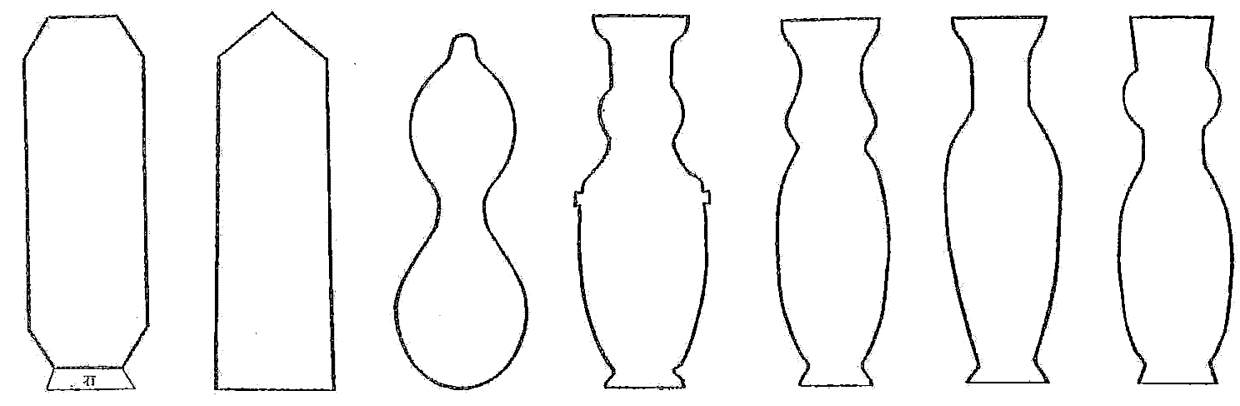

葫壳式

漢瓶式式二

式三

式四

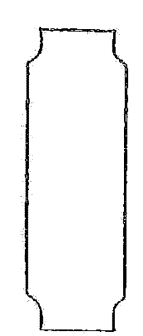

著草瓶式

月空式 片月式
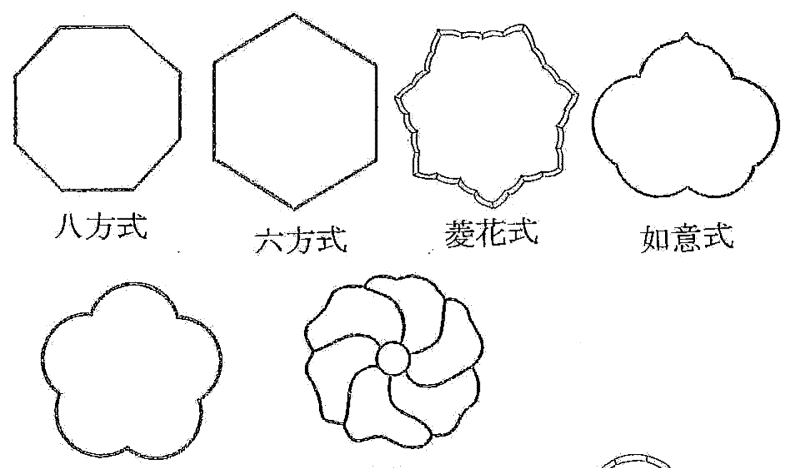

梅花式

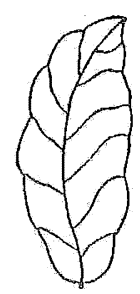

貝葉式

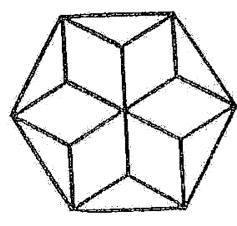

六方嵌㭾子式

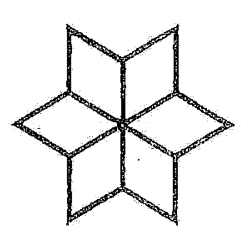

柜子花

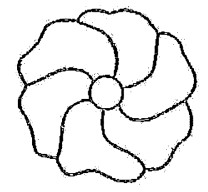

葵花式

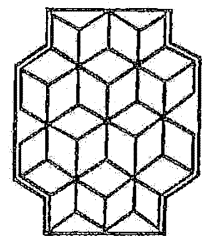

䙮式

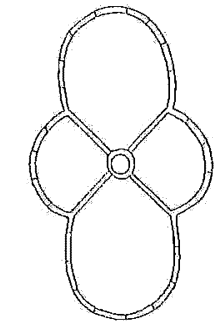

海棠式

【図 2】洞門〔(明) 計成《園冶》隆盛堂版〕 